\title{
Six Sigma Process Definition and Manufacturing Firms in South East Nigeria
}

\author{
AGBAEZE. Emmanuel Kalu, OKAFOR. Godwin Ikechukwu, OHUNYEYE. O. Felix, EKOJA. \\ Geoffrey Owoicho, OBAMEN. Joseph
}

\begin{abstract}
This study examined the Six Sigma process definition evaluation of SME manufacturing firms in South-East Nigeria. The aims of the study include to: define the extent to which the process definition influences customers' patronage; identify the extent to which the process measurement influences product positioning; and establish the extent to which the improvement of production processes influences customers' retention. Three research questions and hypotheses guided the study. The study adopted a survey research design with a multi-stage sampling procedure to select 528 employees from a total of 12 SME manufacturing firms in the South-Eastern parts of Nigeria. The study used a validated instrument to obtain data. The study recorded a $97 \%$ returning rate and the data collected was analysed using a descriptive tool such as percentage and mean, while inferential statistics such as Pearson product moment correlation and linear regression were used to test the hypotheses. The study found that the process definition practice among SME manufacturing firms in the South-Eastern parts of Nigeria profoundly influences customers' patronage $(B=0.530, t=$ 17.398, P-value $=0.000)$. Also, the study built up a significant positive connection between process measurement and product positioning (Pearson $R=0.628, N=512$, \& p-value $<0.05$ ). Likewise, production improvement strategy by SME manufacturing firms in the South-Eastern parts of Nigeria has a high influence on customers' retention (Pearson $R=0.602$, approx. $N=512$, \& p-value $<0.05$ ). The study concluded that, despite the average adaptation of Six Sigma process definition evaluation of SME manufacturing firms in South-East Nigeria, its effect is better-off in many aspects. The study recommended, among other things, intensive effort from management to ensure persistent use of Six Sigma. The study also suggested more commitment towards the adoption of Six Sigma process production approach for SME manufacturing firms in South-East Nigeria to gain all the expected benefits in terms of performance, competitive power, more patronage, customers' retention as well as employee development.
\end{abstract}

Keywords: Six Sigma, Process Definition, SMEs, Patronage, Positioning and Retention

Revised Manuscript Received on November 05, 2019.

AGBAEZE, Emmanuel Kalu, Department of Management, University of Nigeria Enugu Campus, Enugu State, Nigeria

OKAFOR, Godwin Ikechukwu, Department of Management, University of Nigeria Enugu Campus, Enugu State, Nigeria

OHUNYEYE, O. Felix, Department of Management, University of Nigeria Enugu Campus, Enugu State, Nigeria

EKOJA, Geoffrey Owoicho, Department of Management, University of Nigeria Enugu Campus, Enugu State, Nigeria

OBAMEN, Joseph, Department of Management, University of Nigeria Enugu Campus, Enugu State, Nigeria

Corresponding Author: ekojageoffrey2014@gmail.com

\section{INTRODUCTION}

The broad motive for establishing most firms is to generate revenues for its operators when offering products or services that every customer can willingly pay for. However, the competition among manufacturing firms in the South-Eastern parts of Nigeria is forcing the SMEs to come up with unique production strategies that can keep their businesses alive and meet their predetermined goals. Stiffer competition means that a firm needs to increase its production rate as it must ensure that the quality and other aspects such as environmental sustainability and conservation of natural resources which mostly serve as raw materials to the firm, are protected. The zeal to produce more in less time led to the attempt of replacing human workers with machines, which consequently led to the industrial revolution that took place in 1820-1840. Human resources have since been replaced with other forms of machinery. In an account given by Kiely (2011), the initial wastage recorded during the industrial revolution was to the result of comparing the workforce with the machine.

Kiely (2011) reported that men were driven by the machine pace and working under strict conditions. Not only the poor working conditions of the labour force but also the environment was made to suffer for the gains of industrialists. Rosen (2012) explained that after the industrial revolution in the 1990 the world was forced to awaken to the need to save the environment from indiscriminate pollution of heavy smoke from factories, industrial waste as well as incessant chemical by-products discharged into water bodies. In short, the labour, consumers, and the environment have always taken the brunt of industrialists who are bent to lead the market at all cost. The drive for more production in modern-day organisations is still found to negatively impact on employees, consumers, and environments at large, in terms of safety of the workers, quality of the products to be consumed by consumers, and environmental protection from waste and by-products.

The introduction of Six Sigma was not borne without reason; it was an effort to align the production with the conservative method, which reduced waste and maximised the gain, and protected the consumers' interests. Chakrabarty (2009) defined Six Sigma as a formal approach for evaluating, scrutinising, refining, and formerly monitoring or locking-in organisation procedures. Also, Oviri and Brian (2015) expressed that Six Sigma is a complete statistical-based procedure which sets the focus on achieving near excellence in each organisation production cycle.

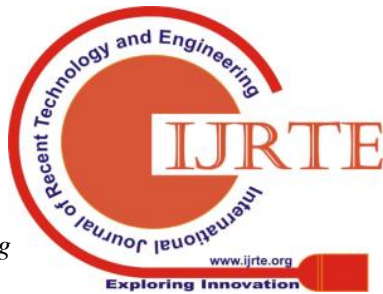


Six Sigma is an assortment of production details guiding organisations to sustain consistent production to meet the demand of target customers (Oko and Parminder, 2015).

Globally, many standard manufacturing firms are adopting the process definition practice with the aim of reducing the production defects and being encouraged how to do it right the first time. Therefore, without doubt, with defects reduced during the production, firms could enhance their benefits of gaining competitive advantage over other competing firms. In today's business environment some products established their dominance in the international markets not because of the production rate from their firms nor their accessibility to more business capital and machinery, but due to their ability to evaluate their process, from production to the end-user (Ngo, 2010). In the developing nations, the business environment and industries have not heavily relied on research centres, which can access the level of acceptance and effectiveness of Six Sigma adoption on their organisations' performance. Likewise, in Nigeria, the business environment and SMEs have not linked directly with various research centres, and little empirical evidence is there to show whether adoption of Six Sigma is paying off or not. There is also insufficient evidence on whether the below-expectation performance by most SMEs is majorly due to the adoption of old technology and lack of adequate process measure. One of the great concerns for business operators, especially those in the manufacturing sector in South-East of Nigeria, is to overcome the persistent failure of meeting annual targets set for the firm. It is always in the interests of business owners to raise the standard of their firms to compete both internally and in the international market; however, lack of consistent product quality has raised the question of whether effective manufacturing firms are adopting the Six Sigma process definition practices. The low level of adoption of Six Sigma SME manufacturing firms in Nigeria including South-East as indicated by Umude-Igbru and Brian (2015) and Suleiman (2014), might be because those enterprises that adopted Six Sigma definition processing Nigeria have little to show for it. Therefore, this study is to empirically evaluate the effectiveness of Six Sigma process definition among SME Manufacturing Firms in the South-East of Nigeria.

\section{Research of Objectives}

The main objective this study is to evaluate Six Sigma process definition of SMEs manufacturing firms in South-East, Nigeria, while the specific aims include to:

i. Assess whether there is an effect of process definition on customers' patronage.

ii. Determine the extent to which process measurement influences product positioning.

iii. Establish whether there is influence of the production processes on customers' retention.

\section{Research Questions}

i. What are the effects of Six Sigma process definition practice on customers' patronage of the SMEs' manufacturing firm's products?

ii. To what extent does process measurement influence product positioning in SMEs' manufacturing firms?

iii. What is the influence of production improvement strategy on customers 'retention in SMEs' manufacturing firms?

\section{Research Hypotheses}

H1: Process definition practice does not affect customers' patronage of the SMEs manufacturing firm's products.

H2: Process measurement does not have a relationship with products positioning in SMEs' manufacturing firms.

H3: Level of production improvement strategy does not have a relationship with the rate of customers' retention in SMEs' Manufacturing firms.

\section{LITERATURE REVIEW}

\section{Concept of Six Sigma Process Definition}

Dahlgaard-Park and Dahlgaard (2006) define Six Sigma process definition as a procedure for joining several quality elements in a firm to generate a chain of supply consumers in the form of a business-two-consumer arrangement. Over the years, the Six Sigma process definition tactics have gained acceptance from many manufacturing firms and aid the firms to come up with varying creativity both in their products and services which keep them ahead of other competing firms. Rosen (2012) argued that process definition through Six Sigma is an undoubted critical business tool that keeps businesses ahead of others irrespective of fast-changing and competitive business environments. Varzandeh and Kamy (2010) maintained that the beauty of Six Sigma process definition makes it adaptable to any business. The adaptability of Six Sigma process definition to every industry including non-manufacturing firms implies its flexibility and adjustability to the organisation's activities.

\section{Parameter for measuring the Six Sigma Process Definition}

Dileep and Rau (2010) argue that Six Sigma process definition enhances cost-effectiveness simply by raising the standard of production in such a way that the defects and rework are extremely minimised. In every production cycle any firm that can guarantee fewer defects and low rework can boast of production efficiency as well as qualitative achievement. Hence, to achieve the anticipated outcomes from production, firms need to set their focus on process definition irrespective of the type of Six Sigma approach chosen (DMAIC or DMADV). DMAIC stands for Defining, Measuring, Analysing, Improving, and Controlling, while DMADV means Defining, Measuring, Analysing, Designing, and Verifying. According to Dileep and Rau (2010) the DMAIC process is suitable for any production firm that wants to improve its existing process thus DMAIC offers upgrading for underperforming production systems in a firm. Meanwhile, the DMADV process is to introduce an improved but new system to an organisation. This is likely to alter the existing production system entirely and raise the quality of products of the firm. However, Dileep and Rau (2010) hinted that DMADV can also be used for augmenting any existing process system if the desire from the firm is to gain more than just increase production. 


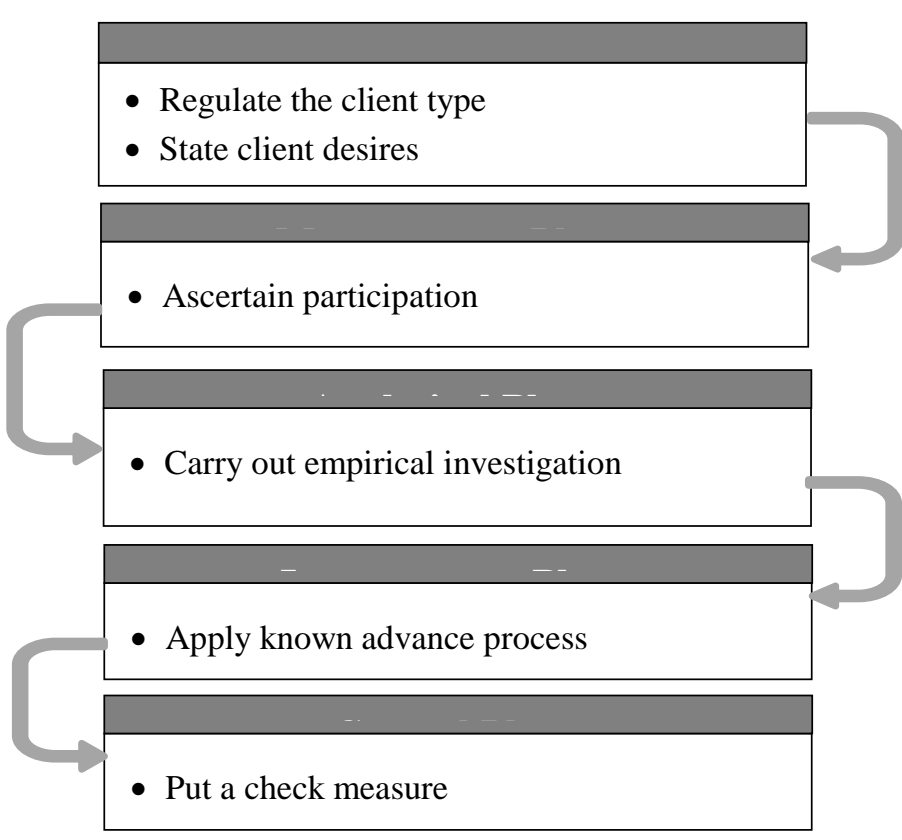

Figure 2.1: Phases of Six Sigma Process Definition

Source: Adapted from Dileep \& Rau 2010. As cited in Daniels, K., Yorlets, R., Flath-Sporn, S., Labow, B., Heald, R., \& Taghinia, A. (2017).). Physician courtesy and patient satisfaction in a pediatric plastic and oral surgery department. Journal of Healthcare Management, 62(3), 211.

\section{Merits of Six Sigma Processing Model}

Through Six Sigma there is usually an improvement in the waiting time, materials, overheads, and quality costs as well as a most significant reduction in the cost of production, as well a reduction in the labour demand. The function of the manager is first to gather some information on how well the firm could perform if all things were put in place. This first diagnostic look will tell the manager what the firm is losing at their current working rate and how well the company could be reshaped to deliver improved products and services. Likewise, Six Sigma looks at basically two aspects, which include how constantly employees in a firm will give the same results at the standard working conditions with little or no motivation, and the probable extent of the enhancement opportunity for the organisation at all stages of production (Okonkwo and Mbachu, 2015). Six Sigma process definition is an approach tailored in the direction of maximising the investors, firms and customers' value in achieving the fastest rate of improvement in customer satisfaction, costs, quality, process speed, and invested capital.

\section{Culture of Six Sigma}

The Six Sigma culture and infrastructure is the encapsulation of standards of changing objectives enthusiastically through persistent improvement and advancement so that any organisation can rapidly execute it (Kumara and Khandujaa, 2013). Six Sigma goes beyond being perceived as only a production enactment approach; rather it encompasses every production structure that can lead to the primary performance of the business among the host of competing firms, and sustain the business to meet the demands and tastes of its customers, stakeholders, employees and other actors. The Six Sigma culture focuses on defining the possibilities opened up for the firms to attain more effective products as well as attaining organisational goals without jeopardising the customers' interests. It is a continuous refinement process to bring the production process close to satisfactory. Malgharni et al. (2011) argued that Six Sigma revealed the capability of production efficiency of any industry through its measurement of process defects in defects per million opportunities.

\section{THEORETICAL FRAMEWORK}

\section{Victor Vroom Expectancy Theory}

The Expectancy Theory, propounded by Victor Vroom in 1964, expresses that the behaviour results from cognisant decisions among options whose reason it is to augment delight and limit torment. He understood that workers' performance depends on people's components, for example, character, aptitudes, information, experience, and capacities. The expectancy theorists such as Edward Lawler (1969) and Lyman Porter in (1972), in their respective efforts to buttress the Victor Vroom expectancy theory, argued that the observable integration among people's action, attitude to work and organisational goals varied from what was early scientists' abstraction. These theorists identified that there is valance among employees, which implies that motivating them uniformly may not necessarily result in better production. The effect of motivation is based on the complexity of the needs of employee extrinsic or intrinsic rewards, which management must ascertain. The ability to discover the causes of defects is addressed by the process measurement phase in the Six Sigma approach, through the identification of various inputs, non-conforming production variables (labour inclusive) as well as types and probable causes (machine or labour) of production defects. Going by Vroom's suggestion, employees' perspectives of expectancy, instrumentality, and valence interact psychologically to create a motivational force that will ensure that the employees act in ways that can lead to production enhancement. Thus, the expectancy theory justified the need for the organisation to persistently review its process to ensure that all production variables are keyed into working efficiently. Providing modern instruments and innovative production techniques might, in turn, motivate some employees that attached value to their success rate as well as engineered consistency in the production standard which is likely to result in the attainment of better product positioning in the competitive business environment.

The synthesis of the review theory showed that the expectancy theory collaborate in the process of Six Sigma to bring the organisational process closer to perfection and eliminate the waste in the process without compromising any variables. Likewise, expectancy theory proved that organisations could use change in process techniques, the improvement of instruments as well as the involvement of employees in fact-finding to non-financially motivate the employees who can, in turn, sustain the product quality and positioning of the product in the competitive market. 


\section{Empirical Review}

Onwughalu, Okeke, and Henry-Chibor (2017) conducted a study to examine the effect of Six Sigma and production among selected business organisations in Port Harcourt, Rivers State. The study-specific objectives included: determining whether adoption of Lean Six Sigma practice influences minimisation of waste associated with variation processing time; and also, whether Lean Six Sigma adoption enhances efficient product supply by manufacturing firms in Port Harcourt. The data used were obtained through records from production unit managers in the studied firms. The extent of the Lean Six Sigma production process among the firms was observed to ascertain their effects in minimising inconsistency related to suppliers, process time and demand. The study adopted a linear regression analysis tool for data analysis. The findings showed that Lean Six Sigma practices had a significant relationship with minimised variations associated with suppliers, processing time and demand; thus, the study concluded that Lean Six Sigma productions assist the industries in eliminating several production wastes and reworks. The study recommended that manufacturing industries, as well as other organisations, should show more persistent adoption of Lean Six Sigma thinking. Also, they suggested the need for more sensitisation campaigns among the manufacturing firms about Lean Six Sigma to cut wasteful practices.

Abidakun, Leramo, Ohunakin, Babarinde, and Ekundayo-Osunkoya (2014) investigated correctness of the Six Sigma technique in the Nigerian fabricating industry. The study examined whether the use of the Six Sigma approach offers better performance for the Nigerian fabricating industry than others and whether a firm can run two approaches concomitantly. Their study adopted DMAIC process definition to identify the sources and causes of production defects in an aluminium mill firm; and to come up with real-time strategy of fabrication in the aluminium mill. Their study showed that the reviewed aluminium mills industries have a $1.87 \mathrm{Six}$ Sigma technique index, which shows further that the firms still have room for improvement to further reduce their rate of re-work or defects. Also, the study argued that those firms that had $37.05 \%$ product quality rate can improve their product acceptance by $4.1 \%$, with Six Sigma technique being adopted throughout the production cycle. They concluded that using Six Sigma offers better performance chances than other methods. Their investigation suggested that the manufacturing firms should change from different standard creation strategies, for example, ISO 9001 and TQM, to Six Sigma if the assembling firms needed any recognisable improvement to prompt the organisations to working with close to immaculate procedures, with insignificant waste and adjustments.

Enoch (2013), examined the influence of Six Sigma adoption on profitability among the small and medium scale manufacturing firms in Nigeria. His main objectives included to determine the extent of implementation of the Six Sigma among SMEs manufacturing in Nigeria and to find whether the adoption of Six Sigma by Nigerian manufacturing firms influences profitability. The study randomly sampled 225 MSMEs comprising of 1026 staff. However, only 1002 employees returned their duly filled questionnaire. The study used Pearson product moment correlation to establish whether or not there is a negative relationship between awareness and Six Sigma usage to achieve expected success factors and profitability. The study found that the adoption of Six Sigma implementation by MSMEs in Nigeria is not significant and thereby has no influence on their profit level. Therefore, it was concluded that failure to adopt Six Sigma by most MSMEs manufacturing in Nigeria accounted for its low impact on their profitability.

Kumara and Khandujaa (2013) conducted an empirical investigation on the application of Six Sigma methodology in the Small-Scale Industries (SSI). They aimed at helping to advance the Six Sigma application in different organisations. The study objectives included to develop better strategies of reducing design defects in a Hydraulic Jack manufacturing firm. The study applied DMAIC methodology targeted at the removal of defects and decrements, and the rejection rate of the pump head of a hydraulic jack set through correcting production defects and enhancing the production process. The data recorded after successful production routines were further analysed using statistical techniques Gauge R \& R method with two sample tests of Factorial method, and control charts. The data obtained prior and after the application of Six Sigma were used to run a process capability analysis. The study established that the application of Six Sigma in SSI helped to improve Zbench Sigma level from 2.21 Sigma to 5.64 Sigma with cost-savings of 0.01929 million/annum. The study concluded that the use of DMAIC is capable of reducing the rejection rate. Thereby, the study recommended that the SME operators, especially the manufacturing industries, should adopt Six Sigma for improved design and enhancement of product acceptability among customers.

Rhodes, Peter, Abe, and Nitin (2011), investigated the roles played by Six Sigma in minimising injury rate among sampled disposal firms. The study objectives included: to determine the uses of Six Sigma process framework in performance management; to explore and improve the injury rate of an international waste disposal firm. The study used Multiple Linear Regression (MLR) analysis. The study established that the Six Sigma management approach leads to safety among employees and eases the managerial task in the sampled organisations. The study concluded that the adoption of Six Sigma plays a significant role in injury reduction among employees. The study recommended that management in the waste recycling industries should not only apply Six Sigma for organisational performance but also to enhance the working conditions of their employees.

\section{METHODOLOGY}

The study adopted a cross-sectional survey research. The choice of this method was based on the fact that the population and sample of this study are scattered in different states across the South-East of Nigeria. The data used were explicitly obtained from primary sources, which involved using the questionnaire to obtain data for research variables. The population of the study comprises all manufacturing firms operating at small and medium scale level, established and operating in the South-East of Nigeria (NBS, 2017). Within the sample frame of 20 firms, representing $10 \%$ of 200, 12 out of 117 firms adopt Six Sigma, and the other eight 
manufacturing firms adopt another production process in the study area. The information gathered from the field was given and investigated with distinct measurements. The hypotheses were tested with the Pearson product moment correlation (PPMC) and regression analysis. A computer supported Microsoft special package for social science (SPSS) was utilised to help examination.

\section{RESULTS}

\section{Results from Analysis of Research Questions}

\section{Research Question One}

What are the effects of Six Sigma process definition practice on customers' patronage of the SMEs manufacturing firms products?

Table 1: Influence of Process Definition Practice amongst SME manufacturing firms in the South-East of Nigeria on Customers' Patronage of their Products

\begin{tabular}{|c|c|c|c|c|c|c|}
\hline $\operatorname{Sin}$ & Items & $\begin{array}{c}\text { SA } \\
\mathrm{Fx}(\%)\end{array}$ & $\begin{array}{c}\mathrm{A} \\
\mathrm{Fx}(\%)\end{array}$ & $\begin{array}{c}\mathrm{SD} \\
\mathrm{Fx}(\%)\end{array}$ & AVG & $\mathrm{RMK}$ \\
\hline 1 & $\begin{array}{l}\text { Your firm's endeavours to decide the } \\
\text { kind of clients before setting out on } \\
\text { generation is profoundly powerful }\end{array}$ & $298(58 \%)$ & $112(22 \%)$ & $102(20 \%)$ & 2.38 & Agree \\
\hline 2 & $\begin{array}{l}\text { Listening to voices from clients before } \\
\text { generation is upgrading supports of } \\
\text { the firm Product }\end{array}$ & $361(71 \%)$ & $81(16 \%)$ & $70(14 \%)$ & 2.57 & Agree \\
\hline 3 & $\begin{array}{l}\text { Prearranging each action before the } \\
\text { beginning of creation is supporting the } \\
\text { firm to satisfy their clients' needs }\end{array}$ & $245(48 \%)$ & $179(35 \%)$ & $88(17 \%)$ & 2.31 & Agree \\
\hline 4 & $\begin{array}{l}\text { The endeavours by the planning unit } \\
\text { of the firm that guarantee passage of } \\
\text { product to the final consumers are } \\
\text { yielding more patronage }\end{array}$ & $298(58 \%)$ & $200(39 \%)$ & $14(3 \%)$ & 2.55 & Agree \\
\hline 5 & $\begin{array}{l}\text { The rundown of exercises utilised by } \\
\text { the planning unit in the firm before } \\
\text { setting out on creation is helping the } \\
\text { firm to address the customer requests } \\
\text { appropriately }\end{array}$ & $209(41 \%)$ & $267(52 \%)$ & $36(7 \%)$ & 2.34 & Agree \\
\hline & Grand Average & & & & 2.43 & Agree \\
\hline
\end{tabular}

SA: Strongly Agree, A: Agree, U: undecided, D: Disagree, SD: Strongly Disagree, AVG: average, Rml: Remark,

\section{Fx: Frequency, (\%): percentages in parenthesis}

The results in Table 1 revealed the extent to which Six Sigma process definition practice among SME manufacturing firms South-East, Nigeria has influenced customers' patronage of their products. The results show that all items have an average score higher than 2.0, the accepted value. The grand average value of 2.43 is higher than 2.0, the accepted value, which indicated that employees in medium scale industries in the South-East of Nigeria unanimously agreed that the process definition influences customer patronage of their products.

\section{Research Question Two}

To what extent does process measurement influence product positioning of the SMEs manufacturing firms?
Table 2: Influences of Processes Measurement amongst SME manufacturing firms in the South-East of Nigeria on Product Positioning in Nigeria markets

\begin{tabular}{|c|c|c|c|c|c|}
\hline Sin & $\begin{array}{lc}\text { Items } & \text { SA } \\
& \mathrm{Ex}(\%) \\
\end{array}$ & $\begin{array}{c}\mathrm{A} \\
\mathrm{Ex}(\%) \\
\end{array}$ & $\begin{array}{c}S D \\
E x(\%)\end{array}$ & AVG & RMK \\
\hline 1 & $\begin{array}{l}\text { The comprehension of external and } \\
\text { mediating contributions to the } \\
\text { production procedure in the firm is } 341(67 \%) \\
\text { giving legitimate product } \\
\text { recognition }\end{array}$ & $112(22 \%)$ & $59(12 \%)$ & 2.55 & Agree \\
\hline 2 & $\begin{array}{l}\text { Steady awareness by your firm } \\
\text { about the plausibility of the non- } \\
\text { adjusting product previously or } 415(81 \%) \\
\text { during the production procedure is } \\
\text { giving the product a good attribute }\end{array}$ & $54(11 \%)$ & $43(8 \%)$ & 2.73 & Agree \\
\hline 3 & $\begin{array}{l}\text { Programmed gathering of data on } \\
\text { different production defects in the } \\
\text { firm is to influence clients' } 167(33 \%) \\
\text { fulfilment }\end{array}$ & $11(2 \%)$ & $334(65 \%)$ & 1.67 & Disagree \\
\hline 4 & $\begin{array}{l}\text { Automatic gathering of data on } \\
\text { potential reasons for the product } 151(20 \%) \\
\text { defects is guaranteeing brand } \\
\text { image in the marketplace }\end{array}$ & $78(15 \%)$ & $283(55 \%)$ & 1.74 & Disagree \\
\hline 5 & $\begin{array}{l}\text { Assurance of the exact cost of } \\
\text { production before setting out on } \\
\text { production procedure is improving } 331(65 \%) \\
\text { the reasonableness of the firm } \\
\text { product to the clients' taste }\end{array}$ & $66(13 \%)$ & $115(22 \%)$ & 2.42 & Agree \\
\hline & Grand average & & & 2.22 & Agree \\
\hline
\end{tabular}

Table 2 revealed the extent to which the Six Sigma process measurement amongst SME manufacturing firms in the South-East of Nigeria has influenced the product positioning in markets. The results show that all items, except items 3 and 4 , recorded average values greater than 2.0, the acceptance value. More so, the grand average value of 2.22 , which is also higher than 2.0 the acceptance value, indicated that the sampled employees from medium scale manufacturing industries unanimously agreed that process measurement is enhancing product positioning.

\section{Research Question Three}

What is the influence of production improvement strategy on customer retention in SMEs manufacturing firms? 
Table 3: Influence of Production Improvement Strategy amongst SME manufacturing firms in the South-East parts of Nigeria on Customers' Retention

\begin{tabular}{|c|c|c|c|c|c|c|}
\hline $\mathrm{S} / \mathrm{n}$ & Items & $\begin{array}{c}\text { SA } \\
\mathrm{Ex}(\%)\end{array}$ & $\begin{array}{c}A \\
\mathrm{Ex}(\%)\end{array}$ & $\begin{array}{c}\text { SD } \\
\mathrm{Ex}(\%)\end{array}$ & AVG & RMK \\
\hline 1 & $\begin{array}{l}\text { Quick response to applying the } \\
\text { important solution for fixing a } \\
\text { deformity in production is } \\
\text { advancing client conviction }\end{array}$ & $398(78 \%)$ & $78(15 \%)$ & $36(7 \%)$ & 2.71 & Agree \\
\hline 2 & $\begin{array}{l}\text { The quick reactions to the } \\
\text { requirements of buyers by your } \\
\text { top management are advancing } \\
\text { service or product customisation } \\
\text { to suit clients }\end{array}$ & $451(88 \%)$ & $45(9 \%)$ & $16(3 \%)$ & 2.85 & Agree \\
\hline 3 & $\begin{array}{l}\text { Meeting financial related } \\
\text { commitment for the } \\
\text { maintenance of equipment and } \\
\text { production plants in your firm is } \\
\text { advancing clients' loyalty }\end{array}$ & $111(22 \%)$ & $67(13 \%)$ & $334(65 \%)$ & 1.56 & Disagree \\
\hline 4 & $\begin{array}{l}\text { Expediting a specialist board to } \\
\text { decide the issue in the } \\
\text { production by your firm is } \\
\text { improving the appropriateness } \\
\text { of the item to the client's taste }\end{array}$ & $356(70 \%)$ & $72(14 \%)$ & $84(16 \%)$ & 2.53 & Agree \\
\hline 5 & $\begin{array}{l}\text { Prompt implementation of the } \\
\text { recommended arrangement is } \\
\text { perfecting the product and } \\
\text { improving upper hands in the } \\
\text { market }\end{array}$ & $365(71 \%)$ & $112(22 \%)$ & $35(7 \%)$ & 2.64 & Agree \\
\hline & Grand Average & & & & 2.46 & Agree \\
\hline
\end{tabular}

Results of Table 3 revealed the extent to which the product improvement strategy by SME manufacturing firms in the South-East of Nigeria has influenced customer retention. The results show that all items have an average value greater than 2.0, except item 3, which has 1.56. This implies that employees agreed that the product improvement strategy influences product positioning. This fact was buttressed further by the grand average value of 2.46 .

\section{Results from Tested Hypotheses}

\section{Hypothesis 1:}

HO: Process definition does not affect customers' patronage of the products.

H1: Process definition positively affects customers' patronage of the products.

Table 4: Result of Linear Regression Analysis of Process

Definition and Customers Patronage amongst SMEs manufacturing firms in South-East Nigeria

\begin{tabular}{|c|c|c|c|c|c|c|c|}
\hline \multirow[t]{2}{*}{ Model } & \multicolumn{2}{|c|}{$\begin{array}{l}\text { Unstandardised } \\
\text { Coefficients }\end{array}$} & \multirow{2}{*}{$\begin{array}{c}\begin{array}{c}\text { Standardised } \\
\text { Coefficients }\end{array} \\
\text { Beta }\end{array}$} & \multirow[t]{2}{*}{$t$} & \multirow[t]{2}{*}{ Sig. } & \multicolumn{2}{|c|}{$\begin{array}{l}\text { Collinearity } \\
\text { Statistics }\end{array}$} \\
\hline & B & $\begin{array}{l}\text { Std. } \\
\text { Error }\end{array}$ & & & & Tolerance & VIF \\
\hline $1^{\text {(Constant) }}$ & 4.103 & .287 & & 14.284 & .000 & & \\
\hline Process Definition & .530 & .030 & .610 & 17.398 & .000 & .641 & 1.56 \\
\hline
\end{tabular}

The results in Table 4 show that there is a significant positive contribution of Six Sigma process definition to customers' patronage $(\mathrm{B}=0.530, \mathrm{t}=17.398, \mathrm{P}$-value $=0.000)$. Hence, the study rejected the null hypothesis which states that process definition does not positively affect customers' patronage. More so, the R2 $=0.37$ and ANOVA F=302.701 at the degree of freedom of 1, 510, suggested that about 37\% variability in the customer's patronage can be explained by Six Sigma process definition among the Six Sigma adopted manufacturing industries. Also, the coefficient of value (B = 0.530 ) suggested that, for every increment in the process definition, SME manufacturing firms in the South-East of Nigeria stand to record 0.53 patronage increment than other manufacturing firms.

\section{Hypothesis Two}

HO: Process measurement does not have a relationship with product positioning.

H1: Process measurement has a positive relationship with product positioning.

Table 5: Result of Pearson Product Moment of Correlation analysis of the Relationship between Level of Process Measure and Products Positioning amongst SME manufacturing firms in South-East Nigeria

\begin{tabular}{|l|c|c|c|c|}
\hline Stat & Value & $\begin{array}{c}\text { Asymp. } \\
\text { Std. } \\
\text { Error }^{\mathrm{a}}\end{array}$ & $\begin{array}{c}\text { Appro } \\
\text { x. T }\end{array}$ & $\begin{array}{c}\text { Approx. } \\
\text { Sig. }\end{array}$ \\
\hline Pearson's R & .628 & .031 & 14.024 & $.000^{\mathrm{c}}$ \\
\hline R-square & .419 & & & \\
\hline $\begin{array}{l}\text { N of Valid } \\
\text { Cases }\end{array}$ & 512 & & & \\
\hline
\end{tabular}

Table 5: The results show a positive significant relationship between Six Sigma process measurement and product positioning (Pearson $\mathrm{R}=0.628$, approx. $\mathrm{T}=14.02, \mathrm{~N}=512$, $\&$ p-value <0.05). In order to determine the statistical importance of the obtained coefficient of correlation, the obtained $\mathrm{R}$ was squared, which yielded 0.419 , indicating that about $42.0 \%$ variability in the product positioning among SME manufacturing firms in South-East Nigeria can be explained by the Six Sigma process measurement.

Hypothesis Three

HO: Level of production improvement strategy does not have a relationship with the rate of customers' retention.

$\mathrm{H} 1$ : Level of production improvement strategy has a positive relationship with the rate of customers' retention.

Table 6: Result of Pearson Product Moment of Correlation Analysis of the Production Improvement Strategy and Level of Customers' Retention amongst SME manufacturing firms in South-East Nigeria

\begin{tabular}{|l|c|c|c|c|}
\hline Stat & Value & $\begin{array}{c}\text { Asymp. } \\
\text { Std. Error }^{\mathrm{a}}\end{array}$ & $\begin{array}{c}\text { Approx } \\
. \mathrm{T}^{\mathrm{b}}\end{array}$ & $\begin{array}{c}\text { Approx } \\
. \text { Sig. }\end{array}$ \\
\hline Pearson's R & .602 & .028 & 17.037 & $.000^{\mathrm{c}}$ \\
\hline R-square & .362 & & & \\
\hline $\begin{array}{l}\text { N of Valid } \\
\text { Cases }\end{array}$ & 512 & & & \\
\hline
\end{tabular}

Table 6: The results show a positive significant relationship between levels of production improvement strategy and levels of customers' retention (Pearson $\mathrm{R}=0.602$, approx. $\mathrm{T}=$ $17.037, \mathrm{~N}=512$, \& p-value $<0.05)$. Furthermore, in order to determine the statistical importance of the obtained coefficient of correlation, the obtained $\mathrm{R}$ was squared, which yielded 0.362 , indicating that about $36.20 \%$ variability in the customer retention for SME manufacturing firms in South-East Nigeria, can be explained by production improvement strategy. 


\section{Discussion of Findings}

1 The findings of this study show that process definition practice amongst SME manufacturing firms in the South-East of Nigeria profoundly influences customers' patronage. The results showed further that the firms' efforts to identify the type of customer as well as listening to their voices before embarking on production are highly useful as customer patronage catalysts. This finding agreed with that made by Alexander et al. (2015) that listening to the customer helps the manufacturing firms to focus on issues that affect customers' satisfaction.

Likewise, the finding made by Cheng (2013) established that the practical application of the Six Sigma process definition built on the capacity of the firm to define their customers by listening to their voices. The current finding concurs with the conclusion drawn by Suleiman (2014) that through the voice of customers, the firms can adjust their production process to address suggestions and requirement of customers to become a key competitor with business excellence. Also, Alexander, Jacqueline, and Jacqueline, (2015) insisted that data capturing should be carried out during the introduction of latest products process as well as at the time of making initiation for a new design to offer sufficient comprehension of consumers' tastes and desires which can serve as significant input during process definition. Also, Abidakun, Leramo, Ohunakin, Babarinde, and Ekundayo-Osunkoya (2014) found that process definition, specifically the voice of product, significantly minimised production defects and offered the firms the opportunity to step on CQM as measure for implementation of Six Sigma process.

2 The findings from this study show that process measurement amongst SME manufacturing firms in the South-East of Nigeria profoundly influenced product positioning in the Nigerian markets. The study established that understanding all production parameters and input requirements for the production process aids a proper corporate image among many other competing products. This finding is in line with that made by Fatoki and Garwe (2010), which established that process measurement in Six Sigma adopted by firms in South-East Nigeria significantly influences the positioning of the brand and firm in many robust competing markets. Also, the findings by Okonkwo and Mbachu (2015) established that any firms that can determine how the process currently performs through proper process measurement are likely to be among the first firms to sell their product in the market, irrespective of competition. Thus, whenever an organisation has a clear idea and adopts appropriate process measurement through the right metrics, there are high chances for such a durable product to be among the taste of the market. Likewise, Oviri and Brian (2015) found that the best way to maintain product attribute is through constant predetermination of the possibility of non-conformity product even before the production process. This shows that customers are always expecting the best and improvement; if, for any reason, there is a substantial drop in the quality of its products, the customers may be left with no option than to opt for other alternative products in the market. 3 Production improvement strategy amongst SME manufacturing firms in the South-East of Nigeria has a high influence on customer retention. Explicitly, it was revealed that prompt fixing of a defect in production promotes customer trust. This agrees with the conclusion drawn by Ika (2012) that process improvement assists the organisation to produce world-class products and services that retain customers much longer. This also agrees with the conclusions drawn by Suleiman (2014) that companies across the world have successfully implemented the process improvement aspect of Six Sigma to improve to a better quality of products or services and maximise retention of customers. The current findings concur with the conclusion earlier drawn by Kumara and Khandujaa (2013) that manufacturing and service organisations mostly preferred to adopt process improvement as a measure to attract more customers to their products. Any organisation with a process improvement measure will never be satisfied with the open design; this takes them out of complacency and opens them to the reason for their customers and potential ones. Also, Rhodes, Peter, Abe, and Nitin (2011) argued that the immediate response to the needs of customers by the firm, which can only be achieved through process improvement, is promoting product customisation to suit customers. The result on the level of productivity improvement through Six Sigma process definition shows that most firms are sustaining all activities to improve their production process except in some cases, which have to do with much financial commitment. Reasons for low performance in the aspect that has to do with finance may not be unconnected with shortages of funds that always face manufacturing firms in a developing country like Nigeria. This result agreed with the findings made by Davenport and Prusak (2010) that access to financial assistance to sustain business process is among the challenges facing most small and medium scale enterprises in a developing nation. Above all, the findings from this study have shown that a significant relationship exists between production improvement strategy and the level of customers' retention, which accounted for having production improvement explaining about $36.20 \%$ variability in the customers' retention amongst SME manufacturing firms in the South-East of Nigeria.

Allowing a process to go out of control implies failures of every other Six Sigma process earlier adopted. In that case, the control of the process is a measure to ensure that all activities in the firms meet the set target and offer the firm the ability to compete with others in the tight economic space.

\section{CONCLUSION}

It could be concluded from the findings that the adoption of Six Sigma Process definition approach is better-off in many aspects. The process definition is key to customers and listening to their voices has significantly increased the consumer patronage. More so, through the a doption of the Six Sigma process definition approach amongst SME manufacturing firms South-East, Nigeria is now achieving effective product positioning among Nigeria markets. This study has also established that the product improvement strategy amongst SMEs manufacturing firms in the South-East of Nigeria has a significant impact on customers' retentions, accounting for about $36.20 \%$ customer retention.

\section{RECOMMENDATIONS}

From the findings and conclusion, the study seeks to recommend; 
1. That the management of SME manufacturing firms should intensify their efforts in other aspects of process definition such as determination of all required resources and facilities before the commencement of production; this will further enhance their rate of customers' patronage.

2. Moreover, the management in the various medium scale manufacturing industries should invest in various automation machines that can aid their process monitoring and measurement and improve their brand positioning among various competing brands.

3 . The management in various medium scale manufacturing industries should persistently carry out process improvement activities in order to keep meeting the customers' tastes and achieve higher customer retention.

\section{REFERENCES}

1. Abidakun, O.A., Leramo, R.O., Ohunakin, O.S., Babarinde, T.O. \& Ekundayo-Osunkoya, A.O. (2014). Quality improvement of foundry operation in Nigeria using six sigma technique. Canada Journal of Pure and Applied Sciences, 8(1), 2751 - 2760.

2. Alexander, D., Jacqueline, D. \& Jacqueline, O. (2015). Lean Six Sigma implementation in East Africa: findings from a pilot study. The Total Quality Management Journal, 27(6), 772-780.

3. Chakrabarty, A., (2009). Six Sigma in service organizations: A conceptual framework based on aspects of implementation and performance. Unpublished $\mathrm{PhD}$, National University of Singapore.

4. Cheng, J., (2013). Linking Six Sigma to business strategy: An empirical study in Taiwan. Measuring Business Excellence, 17(1), 22-32. Emerald Group Publishing Limited.

5. Dahlgaard-Park, S.M. \& Dahlgaard, J.J. (2006). Lean production, Six Sigma quality, and TQM, The TQM Magazine, 10(3), 263-281.

6. Daniels, K., Yorlets, R., Flath-Sporn, S., Labow, B., Heald, R., \& Taghinia, A. (2017). Physician courtesy and patient satisfaction in a pediatric plastic and oral surgery department. Journal of Healthcare Management, 62(3), 211.

7. Davenport, T.H., \& Prusak, L., (2010). Working with six sigma knowledge: How organisations manage what they know. Harvard Business School Press, Boston, MA

8. Edward, E. Lawler (1969). Expectancy theory and job behavior. Organizational behavior and human performance 9, 482-503.

9. Enoch, O. K., (2013). Lean Six Sigma methodologies and organisational profitability: a review of manufacturing SMEs in Nigeria. American Journal of Industrial and Business Management, 3, 573-582.

10. Fatoki, O.O., and Garwe, D. (2010). Obstacles to the growth of new small and medium enterprises in Africa countries: A principal component analysis approach. African Journal of Business Management, 4(2),729-738.

11. Ika, L., (2012). Project success rate through standard techniques: Total quality management, ISO 9000 and Six Sigma among Nigerian project management firm, International Journal of Project Management, 40 (4), 6-19.

12. Kiely, R. (2011). Industrialisation and development: A comparative analysis. UGL Press Limited: 25-26.

13. Kumara, V. \& Khandujaa, R. (2013). Application of Six-Sigma methodology in SSI: A case study. International Journal of Current Engineering and Technology, 3(3), 971-976.

14. Lyman Porter (1972). A study of perceived need satisfaction in bottom and middle management jobs. Journal of Applied Psychology, 4(5), 11-21.

15. Malgharni, A. M., Wan-yusoff, W.F., \& Arumugam, V. C., (2011). The method of measuring and disclosure of non-financial performance. Australian Journal of Basic and Applied Sciences, 5 (12), 1133-1145.

16. Ngo, S.T.Q.N. (2010). The relationship between lean six sigma and organizational performance: An empirical investigation. Unpublished Master Thesis. Lincoln University.

17. Oko, A. \& Parminder, S. K. (2015). Lean Six Sigma Approach to Improve the Admissions Process for a Nigerian HE Institute International Journal of Scientific \& Engineering Research, 6 (5): 22 -29 .

18. Okonkwo, V. O. \& Mbachu, V. M. (2015).A comparative analysis of application of Six Sigma project management technique in small and medium scale construction companies In Nigeria. European Journal of Engineering and Technology, 3 (3), 20 - 25.

19. Onwughalu, O.O., Okeke, K.E. \& Henry-Chibor, E. (2017). Lean Six Sigma production and its effect in organisations: A study of selected manufacturing firms in Nigeria, Scholarly Journal of Science Research and Essay 6 (4), 85-98.

20. Oviri, U. \& Brian, P. (2015). Acceptability of lean six sigma in a developing economy: Results from exploratory research in Nigerian consulting companies. Proceedings of the 2015 International Conference on Industrial Engineering and Operations Management Dubai, United Arab Emirates (UAE), March 3 - 5, 2015.

21. Rhodes, J., Peter, L., Abe, D. \& Nitin B. (2011). The six sigma approach in performance management to reduce the injury rate at work. International Journal of Six Sigma and Competitive Advantage, $1,2,188-205$.

22. Rosen, W., (2012). The most powerful idea in the world: A story of steam, industry, and invention. University Of Chicago Press. p. 149.

23. Suleiman, A. S. (2014). Six Sigma and business environment in Nigeria, IOSR Journal of Business and Management (IOSR-JBM), 16(11), 01-07.

24. Umude-Igbru, O. \& Brian, P. (2015). Acceptability of lean six sigma in a developing economy: results from exploratory research in Nigerian consulting companies. Proceedings of the 2015 International Conference on Industrial Engineering and Operations Management Dubai, United Arab Emirates (UAE), March 3 - 5, 2015

25. Varzandeh, J. \& Kamy, F. (2010). "Comparative and strategic role of ERP in "Six Sigma" Quality". Proceedings of ASBBS, 17(1), 511-517. 